OPEN ACCESS

UWS Academic Portal

\title{
Learning in work
}

Simpson, Amanda; McKechnie, James; Hobbs, Sandy

Published in:

Journal of Education and Work

DOI:

$10.1080 / 13639080.2018 .1479840$

E-pub ahead of print: 05/06/2018

Document Version

Peer reviewed version

Link to publication on the UWS Academic Portal

Citation for published version (APA):

Simpson, A., McKechnie, J., \& Hobbs, S. (2018). Learning in work: perceptions from working teenagers. Journal of Education and Work, 31(4), 433-446. https://doi.org/10.1080/13639080.2018.1479840

\section{General rights}

Copyright and moral rights for the publications made accessible in the UWS Academic Portal are retained by the authors and/or other copyright owners and it is a condition of accessing publications that users recognise and abide by the legal requirements associated with these rights.

Take down policy

If you believe that this document breaches copyright please contact pure@uws.ac.uk providing details, and we will remove access to the work immediately and investigate your claim. 


\title{
Learning in work: perceptions from working teenagers.
}

\author{
Simpson, Amanda ${ }^{a *}$, McKechnie, Jim $^{\mathrm{a}}$ and Hobbs, Sandy ${ }^{\mathrm{a}}$ \\ ${ }^{a}$ Media, Culture \& Society, University of the West of Scotland, Paisley, UK \\ University of the West of Scotland. \\ School of Media, Culture and Society. \\ High Street, Paisley. PA1 2BE. \\ 01418483259 \\ *@vgr877 \\ * amanda.simpson@uws.ac.uk
}

\section{Biographical note}

Amanda Simpson is a Lecturer in Psychology at the University of the West of Scotland. Her research focuses on the skills and abilities that young workers are exposed to in the work place. She recently completed a UWS-Oxfam partnership project on young people's views of decent work. In addition, she has worked on several child employment projects. These include a project for the Department for Education that explored child employment policy and practice in England. [email: amanda.simpson@uws.ac.uk]

Jim McKechnie is a Professor of Psychology at the University of the West of Scotland. His research focuses on national and international aspects of child workers and early experiences of the workplace. As a founder member of the Child Employment Research Group his work has included government funded projects into the nature and extent and policy and practice relating to child employment. [email: jim.mckechnie@uws.ac.uk]

Sandy Hobbs is an Honorary Senior Research Fellow in Psychology at the University of the West of Scotland. He is a founder member of the Child Employment Research Group which has been involved in researching child employment for over two decades. His research has explored young people's experiences of work and government policy and practice in protecting young workers. [email: sandy.hobbs@uws.ac.uk] 


\section{Learning in work: perceptions from working teenagers.}

Research within the UK has shown that it is common for school students to combine fulltime education with part-time employment. Attention has tended to focus on the negative impact this may have with limited consideration to the potential benefits. Some studies have indicated that skill acquisition may be one such benefit, but studies typically pay little attention to the views of young employees and fail to explore potential variations in skill development between age groups and job sectors. This study addresses this gap. Younger (14 and 15 year olds) and older (16 to 18 years) school students working in the retail and catering industries participated $(n=35)$. Two interviews were carried out facilitated by workplace observation and on-the-job event recording. Results suggest that opportunities for acquiring skills are common for both younger and older workers in both retail and catering jobs. Differences in perceptions between age groups and job sectors was small with the exception of the areas of future learning and the types of skills. In addition, retail workers tend to see more opportunities for learning than those in catering. These results support those who see such employment as potentially valuable.

Keywords: school students; part-time employment; skills acquisition

\section{Introduction}

There can be little doubt that school age children are part of the labour market in the United Kingdom. From the earliest modern study of working children in England (Davies 1972) to the most recent large-scale, representative study in Scotland (Howieson, McKechnie and Semple 2006) research has confirmed that it is common for teenagers to combine part-time employment with full-time secondary education.

Howieson et al. (2006) discovered that by the end of compulsory education (approximate age 16) more than half of all pupils had experience of paid work. Employment rose with age and school stage, with the most senior students reporting the greatest experience of work. By the end of secondary education (approximate age 18), eight in ten had experience of paid work. This pattern replicates evidence found in earlier large-scale UK surveys (e.g. Hibbet and Beatson 1995), as well as in smaller, localised British studies (e.g. MacLennan, Fitz and Sullivan 1985; Pond and Searle 1991; Hobbs and McKechnie 1997). The finding is 
also comparable with experience in other developed countries. In Australia, for example, Smith and Patton's (2013) research discovered 64\% of final year school students in part-time employment.

Despite the range of evidence indicating the extent of work during childhood, scant attention has been paid to the context and content of work as experienced by adolescent workers. Few studies have considered the perspective of the young worker and the value their voices can bring to debates about the potential developmental impacts of such experiences. McKechnie et al. (2014) have argued the relative neglect of these experiences is in part due to the dominance of debates concerning the negative impact of work on academic achievement. They argue that the lack of such research reflects the view that adolescents' work experiences are perceived as having little inherent value, due to the type of jobs adolescents undertake. This paper seeks to address this gap by investigating the potential value of employment during adolescence by exploring young workers' views on their experiences of skill acquisition, use and development within the workplace.

Investigating opportunities for learning in American workplaces, Greenberger, Steinberg and Ruggiero (1982), were not encouraged by their findings. They discovered some jobs, like food service, labouring and cleaning offered no opportunities to use school-taught skills, like reading and writing. Student employees spent little time in work with their supervisors and formal work training was rare. Greenberger and Steinberg (1986) contend that the type of work typically undertaken by teenagers is such that no skills are required, and the types of employment offer little opportunity for skill development. In the UK, Mizen, Bolton and Pole (1999) argue that adolescent jobs are characterised by poor quality, unskilled, repetitive manual labour, which is low paid, arduous, and insecure. Subsequent work by Mizen and Pole (2000) suggests that it would be a 'rare occasion' that adolescents would develop any skills via work. 
Leonard (1999) offers an alternative view of school student's employment arguing that even 'simple work' has the potential to be challenging. This could be particularly true for young workers for whom the experience of work is novel. Leonard (2002) therefore cautions against viewing children's work from an adult-centric perspective. Leonard's position seeks not to undervalue or marginalise young people's perspectives and is rooted within the tradition of 'listening to children's voices' (see e.g. Liebel 2004). Evidence collected from working teenagers' own perspectives demonstrates they believe work offers them opportunities to learn specific skills; such as 'people' and 'money-handling' skills (Hobbs et al. 2007). Teenage employees also report their jobs provide them with new understanding about the world of work, and extends their knowledge about work, developing skills that otherwise would not be gained (Leonard 2003).

Similarly, parents of employed teenagers perceive part-time work positively, claiming their children gain confidence and motivation, which, in turn, carries through into their academic and family lives (Phillips and Sandstrom 1990). In the context of debates about the nature of skill development in employment settings, Bryson (2010) notes that we need to acknowledge that skills are not only attained through training and qualifications but that '...skills, knowledge and other attributes are also attained by 'doing', that is through the performance of work...' (p. 2). Some research has begun to explore the specific nature of this potential in adolescents' jobs.

McKechnie et al. (2014) examined a range of school student's work activities and associated opportunities for learning in a variety of job types. They found a majority of workers engaged in team-working and customer-related activities in work. In survey responses over half the sample indicated that they were able to organise their own time and make decisions in the workplace. The research showed that older student employees were more likely to say that their jobs held opportunities for learning and development. McKechnie et al. (2014) also identified variations between age groups and job types in respect of the 'demandingness' of 
the work activities undertaken; which they argued reflected the potential opportunities for learning within a range of jobs typically carried out by students. However, this large-scale survey approach was unable to explore young employees' perceptions of their jobs in detail.

Other research has adopted a qualitative approach to explore workers' perceptions of skills development in work. Using focus groups, Howieson, McKechnie and Semple (2012) learned young workers were positive about skills attainment through employment. In the discussions school students described skills that they gained from working including communication and problem-solving skills, the ability to work in a team, learning to be more responsible, independent and confident, and becoming more aware of the value of money and the need for budgeting.

In interviews with working students, McKechnie et al. (2010) found a number of common themes in the discussion of skills used in work. Most commonly workers believed they had gained communication or 'people' skills, particularly in relation to customers. Second, referring to 'working with others' and 'team working skills' showed relationship skills with co-workers were important. Third, workers felt they had developed their numeracy skills, which was associated with working with money. The final common theme discussed by student workers indicated the perception of gains in self-confidence from the experience. Such studies begin to capture the views of young workers. However, the design of these studies precluded the opportunity to explore variations between age groups and job types.

Evidence such as this challenges the 'no skill' and 'low skill' position adopted by some researchers and emphasises the need for young workers' perspectives on their employment experiences to be considered. Exploring the potential for development in these early employment experiences is important for a number of reasons. First, economic conditions (locally and globally) continue to be challenging. Labour market statistics consistently report the highest rates of unemployment in those aged below 24 (ONS 2017: ILO 2018). Second, employers and employers' organisations routinely complain that school leavers are unprepared 
for the world of work. Surveys of employers of school leavers regularly find around one-third of employers unhappy with their young employees' level of 'basic' and 'core' skills. Employers regard the key skills deficits to include communication skills, the ability to work with others and be organised, skills in literacy, numeracy and problem solving, as well as a general lack of understanding and poor attitude towards work (CBI 2014; Scottish Government 2011; Futureskills Scotland 2009). A Confederation of British Industry (CBI) survey revealed that a majority of employers surveyed believed that schools and colleges should prioritise the development of employability skills in the young in preparation for work (CBI 2012).

Successive UK governments and policy makers have placed the 'employability agenda' high on their lists of priorities (Howieson et al. 2012). In the case of Scotland there have been attempts to address employability within the education system. The introduction of the Curriculum for Excellence (CfE) and Determined to Succeed (DtS) agenda acknowledged the need for school pupils to experience a wide range of economic opportunities in an attempt to increase self-confidence and motivation, and to provide pupils with an understanding of the world of work and employment opportunities available to them (Scottish Executive 2003). Following from this, the Developing Scotland's Young Workforce (DYW) programme seeks to better prepare young people for the world of work with the aim of reducing youth unemployment by $40 \%$ by 2021 (Scottish Government 2014). The voices of those who work during adolescence clearly perceive value and opportunity for learning skills with their parttime jobs. They describe skills that would be useful in post-school employment and are of value to employers. Nevertheless, the potential contribution of the adolescent workplace to the skills and employability agenda is often overlooked by policy makers and schools (Howieson et al. 2012).

Past research has demonstrated that investigations of children's employment experiences must acknowledge the heterogeneous nature of their jobs, as well as factors that may influence work experiences. The early study by Greenberger, Steinberg and Ruggiero 
(1982) showed that opportunities for learning, social interaction and for exercising initiative and autonomy in work varied depending on the type of job employed in. More recently, large scale survey studies (e.g. McKechnie et al. 2014) have shown that age and school stage are important influencers of work experience. Older workers reported significantly more positive attitudes towards learning opportunities in the workplace and greater participation in the work activities examined. Age was also related the type of job one was employed in. Newspaper delivery was predominantly performed by younger workers, while participation in shop-work increased with school stage. Such variations may be associated with different opportunities in work, hence the need to consider both age and job type within the examination of young worker's perceptions of learning skills in work.

\section{Methods}

\section{Design}

Scottish school students in Secondary Years S3 to S6 (14-18 years), who were currently employed in Retail or Catering jobs, were recruited to the study. To compare worker age, students in years S3 and S4 (ages 14 and 15) were allocated to the 'Pre-16' age group, while students in S5 and S6 (ages 16-18) comprised the '16-Plus' group. In Scotland students in S3 and S4 are involved in compulsory education and are subject to 'child employment' legislation, while those in S5 and S6 participate in education voluntarily and are, in the main, subject to adult worker legislation.

Students were further grouped based on their employment type. Retail and Catering jobs were selected as these occupations are the most dominant forms of work in school-age workers (Howieson et al. 2006). The sample therefore comprises of four groups; 'Retail Pre16', 'Retail 16-Plus', 'Catering Pre-16' and 'Catering 16-Plus'. Between-sector ('Retail' and 'Catering') and between-age group ('Pre-16' and '16-Plus') evaluations are considered. 


\section{Participants}

Thirty-five working students were recruited from local secondary schools in the West of Scotland region. A majority of the sample $(63 \%)$ were female. Sixteen were employed in Retail jobs (46\%), and nineteen in Catering work (54\%). 'Pre-16' workers comprised $46 \%$ of the sample $(\mathrm{n}=16)$ and 54\% ( $\mathrm{n}=19)$ were '16-plus' workers. Table 1 details the age and gender composition of each job type.

[Table 1 near here]

\section{Procedure}

The data presented in this paper is drawn from a wider study of the paid employment undertaken by school students. That study contained four main elements:

(1) Initial Interview: Participants were asked about activities undertaken in their jobs, workplace training, relationships with others at work, and what skills were used and developed in their jobs. In addition, they were asked about what new skills they had gained from their work experience, what existing skills they had developed at work, and what potential their jobs had for future skill development.

(2) Event Recording: Participants were equipped with a mobile phone, set to activate five times in a period of one hour. On receiving the signal, participants completed a short questionnaire covering the activities in which they were currently engaged, social contacts and levels of satisfaction.

(3) Observation: A researcher spent a period of one hour making a narrated commentary describing the participant's activities and the range and nature of social contacts made. 
(4) Second Interview: Participants were asked for their general views on 'quality of work' and to reflect on what skills were needed for their jobs. The interviewer made reference to what had happened in stages 2 and 3 to facilitate this discussion.

Since the focus of this paper is on workers' perceptions of their jobs, this paper draws on the two interviews as the principal data sources. Previous research findings had indicated that young workers are unused to talking about their experiences at work (Hobbs et al. 2007), and this research design was employed to facilitate discussion. In the second interview, the event recording and observation period were valuable reference points which contributed to more profound statements by the participants than would usually have been achieved in the opening interview.

\section{Skills Coding}

To identify the range of skills identified in all the jobs represented in the study, each interview was explored using the 'Descriptive Coding' method as described by Miles and Huberman (1994) and summarised by Saldana (2009). This method assigns basic descriptive labels, or tags, as meaning to the data. This 'meaning' can be descriptive or inferential (Miles and Huberman 1994), but essentially results in a 'categorised inventory... or index of the data's contents.' (Saldana 2009, 72). In this regard the 'codes' or labels are reflections of the topic the respondent is describing (Tesch 1990). Participants retained agency over the discussion of skills, and no external evaluation was placed on the validity of the skills discussed. Workers' narratives across both interviews identified a total of 54 unique skills. Interpretation of the skills noted by workers identified five main categories of skill. These were interpersonal (IP), task-related (TR), personal attributes (PA), job knowledge (JK) and physical characteristics (PC). To explore variations in experience, skills profiles were constructed for each participant detailing the number and type of skills they each perceived in their jobs. To explore perceptions of existing, new and future skills, frequency counts of responses were taken, and the qualitative 
commentary evaluated. Gibbs's (2007) 'constant comparison', 'memo writing', and 'code cross-checking' techniques were employed to enhance the reliability of the coding and categorisation.

\section{Findings}

\section{The perceived nature of skills in work}

To examine the extent to which young workers perceived their jobs as able to offer opportunities for the use and development of skills, a 'skills profile' was created for each participant detailing the type and number of skills discussed by them. Exploration of workers' narratives was conducted from the perspective of considering the level of contrast or similarity between sectors and age groups (Retail Pre-16, Retail 16-plus, Catering Pre-16 \& Catering 16plus).

First, the number of skills participants identified as needed in their current jobs was explored (Table 2). Differences between employment sectors and between age groups are small and non-significant.

[Table 2 near here]

Although we found little difference between employment sectors and age groups in the overall frequency of perceived skill requirements, a key focus of this study was to explore potential variations between groups in the types of skills reported.

Figure 1 provides an overview of the prevalence of the main skill categories by sector and age. The relative proportion of each category is comparable for each group of employees. For example, physical characteristics is the smallest category in all groups. One exception to this pattern can be observed in the Catering Pre-16 group where the employees reported fewer instances of skills that fell into the interpersonal category and a higher percentage of skills that 
were task related. This would suggest that there is some variation between the sectors and age groups in the skills that employees identified from their work experience.

[Figure 1 near here]

As noted in the Methods section we used a 'skill category' approach to classify the range of individual attributes identified as 'skills' by the employees. Consideration of these individual skills allows us to consider the level of consistency and variation between sectors and age groups.

For example, in the interpersonal skills category, the role of communication skills was identified as being of importance but was referred to more often by those working in Retail and in the older, 16-plus, age group. Such findings indicate that age and sector type may interact in influencing awareness of specific skills. Older workers may be more aware of this type of skill and aspects of Retail employment interactions may increase the saliency of the skill.

The importance of communication skills is reflected in the workers' comments;

'You're dealing with customers... all the time so... like before obviously I wasn't really having contact with like just members of the public and strangers really' (Kelly, Retail 16-plus).

'I'd say I'm probably a wee bit better at communicating cause I've had a lot more contact with customers than I did at Tesco so that's kind of improved...there's a lot more interaction between me and the customers' (Elaine, Catering 16-plus).

Post-16-year-old employees were more likely to expand on the relevance of communication in a wider number of contexts: 
'...in work I've got workmates, colleagues and, managers and different customers, complete strangers' (Martin, Retail 16-plus).

The link between exposure to customers and interpersonal skills is further evidenced by the kinds of skills that were uniquely identified in each group. Retail workers discussed the need to be considerate and aware of disability needs when dealing with customers. Catering workers on the other hand discussed the need for team working and management skills which they related to working with other employees. This suggests that while interpersonal skills are important in both sectors, customer demands in Retail work may drive the greater perceived need for skills of an interpersonal nature, while in Catering it is the need to work with others that influences the type of interpersonal skills needed in the role.

As Figure 1 shows task related skills were reported by all groups. The type of skills linked to this category included numeracy skills and the ability to operate machinery. Employees in the Catering sector were more likely to report using kitchen-based machinery while Retail workers referred to the need to operate cash registers and computers. Variations also emerged for age groups where young workers (Pre-16) reported cleaning skills, while none of the older employees referred to these skills. Similarly, older workers reported the need for multi-tasking skills, while this skill set was not mentioned by the younger employees. Some skills were only mentioned by Catering workers (e.g. food preparation, memory, plate carrying skills) indicating that exposure to some skills is sector specific.

In a number of instances an interviewee would identify a skill that no one else did. This tended to be arise in cases where the nature of the job required a specific skill e.g. setting tables, blow-drying hair. Examples of these 'unique' skills were more prevalent amongst those working in the Retail sector and may reflect the diversity of jobs within this sector (see Table 1). In contrast Catering work is more tightly focused on reporting food-related skills. 
The personal attributes category includes skills referred to by employees such as common sense, observation and organisational skills. In Retail and Catering the older workers made more reference to these skills (Fig. 1);

'Common sense as well, ... if there's something wrong, or ... to stay within the rules... if there's two tasks that are needing done you need to...use your common sense and say what one's more important' (Chris, Retail 16-plus).

'.... you need to be able to kinda keep up with whatever's going on as well, coz it can get really busy and you've got to keep up with what's this and where's it going....' (Emma, Catering 16plus)

Younger employees made more reference to organisational and motivation skills, compared to the older workers, suggesting that when one starts work the relevance of such skills may be more salient. In addition to the variation between the age groups some differences emerged between the job sectors. Catering workers were more likely to refer to organisation skills, motivation and efficient working. This may reflect the demands associated with different jobs. For example, working in a café may require the need to co-ordinate actions with other team members to deliver a food service.

Job knowledge was identified as important for all employees:

'You need to know everything about the work, so like the job and everything like that, so that people can ask you a question and you can quickly answer it' (Karen, Retail Pre-16).

As Figure 1 shows this was not the dominant skills category for any of the employee groups but was represented in each one. The skills identified by the interviewees included 
product knowledge, location of items and awareness of their job roles. Those in the Catering sector were more likely to refer to hygiene skills reflecting the specific nature of this type of job. Younger workers focused more on the skill of knowing about their own job role and what was required of them. It is possible that older workers, who may have more work experience, were more familiar with the expectations that others have of them in the work place.

It is clear that young workers can identify a range of skills that they require in order to carry out their part-time job roles. The interview data identified a number of similarities that cut across both age groups and job sector. However, there are a number of examples of age and sector differences. These findings demonstrate the ability of young workers to articulate the range of skills they associate with their employment.

\section{Opportunities for learning in work}

To explore the question of whether the workplace offers opportunities for young people's learning, the interviewees were asked to reflect upon any new skills they had learned from their jobs, whether existing skills had changed because of work, and lastly, whether their jobs provided opportunities to learn new skills in the future.

Only four employees (two Catering, two Retail) expressed the view that they had failed to learn any new skills in work. The remaining $28(88 \%)$ were more positive in their responses indicating that they had gained new skills. There were no significant age or job sector differences suggesting that attaining new skills may be common for young workers.

For a small number of our interviewees $(n=3)$ every skill they identified during the interviews was a 'new' skill obtained from their current jobs. However, for the majority of workers a number of new skills gained from work was complimented by the development of 'existing' skills. The most commonly reported was task-specific skills, such as learning the operation of a piece of machinery. Also common was that of gaining new interpersonal skills, including communication skills and gaining in confidence. Chris (Retail 16-plus) discussed 
how his confidence in talking to older people had developed. Although comfortable with people his own age, work had developed new skills to converse with adults:

'..... I've picked up... I can, talk to them [older people], more instead of looking at them as if they're different like I can actually just look at them and say I can talk to them as so I'm confident within like the whole age range...' (Chris, Retail 16-plus).

Other employees echoed this idea indicating that their work had helped them overcome shyness and had given them the confidence to deal with strangers:

'...... you are more confident, you learn from it do you know what I mean..... 'cause you're forced to do that, you kinda have to if you want to serve somebody.....' (Julie, Retail 16-plus).

In the case of one of our interviewees her work experiences had taught her how to manage challenging interactions with customers:

'...occasionally there's people that aren't allowed in the shop cause they're known as shoplifters and there's like disabled people as well sometimes and you would have to help them out and things like that.' (Meg, Catering 16-plus)

Amongst those employees who felt that they had failed to gain any new skills from their jobs there was a tendency for them to indicate that their work did not require many skills in the first place. One indicated that they did not learn anything new because their job involved just 'basic everyday things'. Within this group another interviewee indicated that they had past experience in the same industry, and that their current post was more restrictive than the previous one (in which they had learned new skills). The responses from this small group of 
workers indicates that we should not assume that all jobs provide young workers with opportunities to gain new skills. Similarly, we need to acknowledge that after gaining some experience in certain jobs the opportunity to learn new skills may reach a plateau.

Rather than gaining new skills, work experience may enhance existing skills and the majority $(n=26)$ of our interviewees believed that this applied to their employment experience. The primary skill area that benefitted from this related to the category of interpersonal skills, with a focus on customer contact. For example, communication skills improved in that interviewees commented that they were able to 'help people more', 'talk to different people', and 'work with disabled people'. Other skills that participants felt had developed included the ability to motivate themselves, organisation, job-specific food preparation skills, and numeracy and literacy skills. For example, motivation was highlighted by a number of interviewees and in some cases respondents explained how skills based in work transferred to other parts of their life:

Like usually if there was a lot stuff to get done, and like the past I might just have said oh I'll just put it to like, put it to the back of my head ... if I had loads of homework or something like that, I'd just do some of the homework and say I'll get the rest later, whereas my job it actually forces you to do it... that's what I think helped me quite a lot with my Highers [exams], cause, with that when I do get a lot of homework I just say right get through it ... so it does help me quite a lot. (Chris, Retail 16-plus).

As was the case with new skills, there were no significant variations between job sector and age groups regarding the identification of the development of existing skills. It would appear that both Retail and Catering sectors offer such opportunities to both age groups. A minority of workers $(n=6)$ were of the view that their jobs did not develop their existing skills. The majority of this group were Catering sector workers (5 Catering vs 1 Retail). Half of these 
employees expressed the view that every skill they thought they had was a new skill gained as a result of their current employment experience. In that sense their work had not enhanced existing skills but developed new skills. The remaining three workers indicated that their existing skills had stayed the same in the current job.

The relatively small number of workers who felt that they did not develop existing skills suggests that irrespective of job sector or age group, employment experience creates opportunities for enhancing pre-existing skills. We will return to this issue of consistency of experience across all jobs in the discussion section.

The final area we explored with our interviewees was the potential for future skill development in their jobs. Table 3 provides a summary of Yes/No response to the issue of whether their current job has the potential to enhance future learning. Half of the sample is pessimistic about future learning opportunities. While there was some variation between the age groups the differences between the job sectors is most marked. Compared to the Catering sector, Retail workers were significantly more likely to believe that their jobs offered opportunities for future learning $\left(\chi^{2}\right.$ Yates $\left.(1, \mathrm{n}=32)=7.91, \mathrm{p}=.004, \varphi=.56\right)$.

[Table 3 near here]

Overall young Retail workers were more positive in their views when discussing future learning;

'......I'll need to learn how to put up the computer and stuff so I'll be learning new skills for that ... like to speed things up and do things faster......' (Tracy, Retail Pre-16).

'....so they count in how many stock we've got and when it's going to get, get delivered and stuff ..... if I stayed on I'd be able to like, learn that and help with that....' (Martin, Retail 16plus). 
Amongst those employees who were pessimistic about future learning opportunities a common theme emerged to explain this. For these workers, the main limitation for future opportunities lay in the nature of their employment, that is, they are 'part-time' workers. The implication is that their status limits the potential to develop in the workplace. It is possible that the divide between the opportunities open to part and full-time workers is more marked in the Catering sector and may be linked to food preparation. For others, the issue was that there was not much to learn in their jobs. Once they had attained the key skills it was about repetition:

'...... because I've done all my training and things now but there was a lot during the training like and the patience and the hard working and stuff, but now that I've finished the training it's just going to be like, keep that up....' (Anna, Catering Pre-16).

Other employees thought that there was potential for future learning but that this would only be possible if something about their job changed. Karen (Retail Pre-16) provides an example of this:

'Yeah because it changes, 'cause now I've been able to make like the coffee, before that I couldn't even make a cup of coffee for my own house never mind in the machine thing, and I can make smoothies and everything 'cause the works changed ... so if it changes again then I'll be able to do something else....'

In this case there is evidence of initial learning being expanded as their place of work diversified and offered new drinks (smoothies). This experience leads them to consider that future learning possibilities may appear but that they cannot predict this. 
In summary, across all of the interview material, only one of the workers was of the view that they had not learned any new skills or developed existing skills as a result of their current job:

'There's really not that much to know, pretty much anybody could do it' (Gary, Catering Pre16).

However, even in this case further discussion with Gary revealed that this view was related to his current job. He had worked in a previous role within the same workplace and confirmed that learning had taken place in that role. Based on the evidence provided by the young workers in our study it is evident that they perceive that their employment provides opportunities for learning.

\section{Discussion}

Young workers' voices in this study are clearly telling us that they have the opportunity to develop and use skills in the workplace. All workers reported the need for skills in their jobs and the majority believed that they had acquired and developed skills as a result of their experiences of the workplace. Across both age groups and job categories a picture of consistency emerged that indicates that jobs commonly held in adolescence are a perceived source of opportunities for learning and developing skills. Even the most critical voices on this issue did not reflect a position of 'no learning' which underlines the importance of considering the perspective of the young worker. As Leonard (2002) argues, this issue must not be considered from an adult perspective.

The matter of future learning was the area of greatest between-group disparity. In contrast to Catering employees, Retail workers were more likely to indicate that there was potential for learning new skills. Catering workers perceived fewer opportunities for future learning. This belief related closely to the perception and experience of the retail workplace as 
a dynamic, changing space. A key limitation to opportunities for future learning was the young employees 'part-time' status. It may be that for employers have limited hopes of what they can expect from young part-time employees or realise that this labour force may be susceptible to change. Such views would lead them to limit their expectations and opportunities for this group of workers. If this is the case then it should make us cautious regarding our expectations of what can be gained from work. Jobs may still be 'low skilled' and have limits to their ongoing potential.

A further area of variation related to the type of skills perceived as needed in the workplace. Workers' narratives indicated that Retail work was perceived as being more interpersonal and customer orientated. In contrast Catering work was viewed as more colleague orientated, with the added dimension of food-related skills with less focus on customer-relevant skills. Small age-related variations also emerged with younger workers reporting different types of solitary skills, such as cleaning and the older group reliant more on skills of an interpersonal nature. Nevertheless, many skills were common in both sectors and age groups.

Previous research tells us that the type of work undertaken is likely to vary between job sectors (Greenberger et al. 1982) and by age (McKechnie et al. 2014). This would lead us to assume that we may have found variations between our job sectors and age groups. However, while several variations in the specific, individual types of skills identified by groups were discovered, at the general category level the nature of the types of skills reported was comparable between the age groups and job sectors. This would suggest that there is some consistency in the employment experience of young workers in terms of workplace learning potential.

On the subject of the types of skills, critics such as Mizen and colleagues (1999) might argue the skills identified by workers in the study are not of a 'high skill' nature. Others might question the validity of some of the skills identified by workers. For example, knowing where items are kept in work, being 'friendly', or having 'confidence' may not be considered by all 
as 'skills'. However, the young employees in this study considered them to be of value and Besen (2006), like Leonard (2002), has cautioned against using adult 'meta-narratives' to understand adolescent work. Adult-centric perspectives might fail to capture the range of possible learning evident in these workers' voices.

When asked, workers in this study identified that their jobs offered the opportunity to use, develop and learn skills relevant to the workplace. Workers described a wide range of skills and abilities including those that could be considered generic and transferable, such as 'people skills' or 'numeracy', as well as the more job-specific type, for example 'food preparation'. These skills are closely comparable with those identified by UKCES, a UK Commission set up to research employment issues relevant to employability skills.

In a review of twenty published definitions, UKCES (2009) identified a broad range of skills including communication, working with IT, application of number and numeracy, skills for working with others, thinking and problem-solving skills, self-management and ability to learn, positive work attitudes and behaviours, organisational skills, customer relationship ability, and literacy skills, as well as other personal characteristics such as being dependable, reliable and innovative. In respect of findings from this study, it is possible to argue that adolescent workers can learn in-work skills that are considered valuable in the adult employment sphere.

In keeping with the broader 'employability' agenda, interpersonal and communication skills are particularly important for workers in this study. Workers perceived the opportunity to gain and develop interpersonal skills from the more generic proficiencies such as 'people skills' and 'communication' to the more specific examples such as being 'polite', having 'patience' and being 'friendly' to others. Employers and employer groups perceive these types of 'soft', 'core' skills as high priority within the workplace (CBI 2014). Workers in the study emphasise the significance of having these skills particularly for dealing with customers within their work environment. 
The idea that interpersonal skills are particularly important for development of adolescents is not a new one (e.g. Steinberg and Cauffman 1995) but little attention has been paid to the context and content of adolescent work and this lack of interest includes that of the social experience of work. A useful addition to the child employment literature might focus on interrogating the nature of these interpersonal skills, and the activities that help develop them. For example, investigation of the interactions with fellow workers may reveal aspects of peer to peer learning or the establishment of workplace norms and attitudes.

The type of skills identified by young workers may be considered 'basic', or 'soft', but they are also considered 'core' and 'essential' (UKCES 2009) and fresh consideration of the adolescent workplace is needed to start interrogating the value of the skills learned. One question might focus on the long-term significance of gaining advanced interpersonal skills early in adolescence. Researchers like Leonard (1999, 2003), Howieson et al. (2006), and McKechnie et al. (2010) identified that the opportunity to learn and develop new skills in work is valued by young workers. This study shows that employment in Retail or Catering offers those opportunities to adolescent workers.

In contrast to previous research (e.g. Howieson et al. 2012) the present study found more widespread evidence of opportunities for learning in the work place. All workers reported developing workplace skills, either through the development of existing or the acquisition of new skills. In contrast to some previous research this study adopted a qualitative approach, and this may provide greater insight into young workers perceptions of their work. Both McKechnie et al. (2010) and Reynolds (1991) demonstrated that young workers tend to under-report the range of activity they do in work.

However, we should not assume that there are no challenges to be faced in adopting a qualitative approach. For example, Hobbs et al. (2007) argued that young workers tend not to be very good at discussing work experiences and often change or qualify their initial statements about work. The methodology adopted in this study may have countered some of these 
concerns by providing multiple contact points and as such facilitated a deeper exploration of employment experiences. Adopting this type of approach has highlighted that the opportunities and experiences of learning in the adolescent workplace may be more widespread than previously thought.

Further research is of course required to consider the generalisability of the conclusions from this study. The focus of this paper was on the two dominant employment sectors for young employees, retail and catering. The failure to identify any major variations between younger and older employees may be related to the focus on these sectors. Both sectors share a customer-service focus, and this may account for the limited age and sector variations found in the present study. Exploration of other job types, involving a wider range of work activity, would allow us to consider whether this type of work experience supports the development of generic skills or job specific skill sets.

\section{Acknowledgements}

Grateful thanks are offered to all of the young workers involved in the research.

\section{References}

Besen, Y. 2006. Exploitation or fun? : The lived experience of teenage employment in suburban America. Journal of Contemporary Ethnography 35 (3): 319-340.

Bryson, J. 2010. Beyond skill - An Introduction. In Beyond Skill, edited by J. Bryson, 1-7. London: Palgrave Macmillan, London.

Confederation of British Industry. [CBI]. 2012. Learning to Grow: what employers need from education and skills. Education and Skills Survey 2012. London: CBI/Pearson.

Confederation of British Industry [CBI]. 2014. Gateway to Growth: CBI/Pearson Education and Skills Survey 2014. London: CBI/Pearson.

Davies, E. 1972. Work out of school. Education, 10: i-iv.

Futureskills Scotland. 2009. Skills in Scotland 2008. Edinburgh: The Scottish Government. Accessed July 7 2017. www.scotland.gov.uk/Resource/Doc/263613/0078884.pdf 
Gibbs, G. 2007. Analyzing Qualitative Data. London: SAGE Publications.

Greenberger, E., and L. Steinberg. 1986. When Teenagers Work: The Psychological and Social Costs of Adolescent Employment. New York: Basic Books.

Greenberger, E., L. D. Steinberg and M. Ruggiero. 1982. A Job Is a Job Is a Job ... or Is It? Work and Occupations 9 (1): 79-96.

Hibbett, A., and M. Beatson. 1995. Young People at Work. Employment Gazette, 103 (April): 169-177.

Hobbs, S., and J. McKechnie. 1997. Child Employment in Britain: A Social and Psychological Analysis. Edinburgh: The Stationery Office.

Hobbs, S., N. Stack, J. McKechnie, and L. Smillie. 2007. Talking about work: School students' views on their paid employment. Children \& Society 21(2): 123-135.

Howieson, C., J. McKechnie, and S. Semple. 2006. The Nature and Implications of the PartTime Employment of Secondary School Pupils. Edinburgh: Scottish Executive.

Howieson, C., J. McKechnie. and S. Semple. 2012. Working pupils: challenges and potential. Journal of Education and Work 25(4): 423-442.

International Labour Organization [ILO]. 2018. Unemployment, World. Data Finder - World Employment and Social Outlook. Accessed January 27 2018. https://goo.gl/Rd1SrA

Leonard, M. 1999. Play Fair with Working Children: A Report on Working Children in Belfast. Belfast: Save the Children.

Leonard, M. 2002. Working on your Doorstep: Child Newspaper Deliverers in Belfast. Childhood 9(2): 190-204.

Leonard, M. 2003. Children's attitudes to parents', teachers' and employers' perceptions of term-time employment. Children \& Society 17(5): 349-360.

Liebel, M. 2004. A will of their own: Cross-cultural perspectives on working children. London: Zed Books.

MacLennan, E., J. Fitz, and J. Sullivan. 1985. Working Children. London: Low Pay Unit.

McKechnie, J., C. Howieson, S. Hobbs, and S. Semple. 2014. School students' introduction to the world of work. Education + Training 56 (1): $47-58$.

McKechnie, J., S. Hobbs, A. Simpson, S. Anderson, C. Howieson, and S. Semple. 2010. School students' part-time work: understanding what they do. Journal of Education and Work 23(2): 161-175.

Miles, M. B., and A.M. Huberman. 1994. Qualitative Data Analysis: An Expanded Sourcebook. $2^{\text {nd }}$ ed. Thousand Oaks: SAGE Publications.

Mizen, P., A. Bolton, C. Pole. 1999. School Age Workers: The Paid Employment of Children in Britain? Work, Employment \& Society 13 (3): 423-438. 
Mizen, P., and C. Pole. 2000. Why work at the edge? The motivations for working among school age workers in Britain. Bulletin of the International Conference on Rethinking Childhood: Working Children's Challenge to the Social Sciences, No, 3. Institut de Recherche pour le Développent, Paris.

Office for National Statistics [ONS]. 2017. Unemployment rate (aged 16 and over, seasonally adjusted). Accessed August 182017.

https://www.ons.gov.uk/employmentandlabourmarket/peoplenotinwork/unemployment/times eries/mgsx

Phillips, S., and K.L. Sandstrom. 1990. Parental Attitudes toward Youth Work. Youth \& Society 22(2): 160-183.

Pond, C., and A. Searle. 1991. The Hidden Army: Children at Work in the 1990's. London: Low Pay Unit.

Reynolds, P. 1991. Dance civet cat: Child labour in Zambezi valley. London: Zed Books.

Saldana, J. 2009. The Coding Manual for Qualitative Researchers. London: Sage Publications.

Scottish Executive. 2003. Determined to Succeed: Enterprise in Education, Scottish Executive Response. Edinburgh: Scottish Executive.

Scottish Government. 2011. Skills in Scotland 2010. Glasgow: Education Analytical Services.

Scottish Government. 2014. Developing the Young Workforce: Scotland's Youth Employment Strategy. Edinburgh: The Scottish Government. Accessed February 2018. http://www.gov.scot/Resource/0046/00466386.pdf

Steinberg, L., and E. Cauffman. 1995. The impact of employment on adolescent development. Annals of Child Development 11: 131-166.

Smith, E., and W. Patton. 2013. Part-time working by students: is it a policy issue, and for whom? Journal of Education and Work 26(1): 48-76.

Tesch, R. 1990. Qualitative Research: Analysis Types \& Software Tools. London: RoutledgeFalmer.

UKCES. 2009. The Employability Challenge. Accessed August 52015. http://www.agcas.org.uk/articles/207-New-report-outlines-UKCES-employability-drive 
Table(s) with caption(s) (on individual pages)

Table 1: Participant sample by job sector, age, gender and type of job

\begin{tabular}{|c|c|c|c|}
\hline Job Type & Participants* & Gender & Job description \\
\hline $\begin{array}{l}\text { Retail } \\
\text { Pre-16 } \\
(\mathrm{n}=6)\end{array}$ & $\begin{array}{l}\text { Alice } \\
\text { Tracy } \\
\text { Ruth } \\
\text { Karen } \\
\text { Scott } \\
\text { Craig }\end{array}$ & $\begin{array}{l}\mathrm{F} \\
\mathrm{F} \\
\mathrm{F} \\
\mathrm{F} \\
\mathrm{M} \\
\mathrm{M}\end{array}$ & $\begin{array}{l}\text { Corner Shop Shelf Replenisher } \\
\text { Junior Tanning Salon Assistant } \\
\text { Opticians Assistant } \\
\text { Sweet Shop Assistant } \\
\text { Trainee Cobbler (Shoe repairs shop) } \\
\text { Junior Hairdresser }\end{array}$ \\
\hline $\begin{array}{l}\text { Retail } \\
\text { 16-plus } \\
(\mathrm{n}=10)\end{array}$ & $\begin{array}{l}\text { Kelly } \\
\text { Joanne } \\
\text { Pamela } \\
\text { Jack } \\
\text { Julie } \\
\text { Debbie } \\
\text { Stephen } \\
\text { Martin } \\
\text { Gordon } \\
\text { Chris }\end{array}$ & $\begin{array}{l}\mathrm{F} \\
\mathrm{F} \\
\mathrm{F} \\
\mathrm{M} \\
\mathrm{F} \\
\mathrm{F} \\
\mathrm{M} \\
\mathrm{M} \\
\mathrm{M} \\
\mathrm{M}\end{array}$ & $\begin{array}{l}\text { Jewellery Sales Assistant } \\
\text { Health and Beauty Sales Assistant } \\
\text { Sweet Shop Assistant } \\
\text { Health and Beauty Shelf Replenisher } \\
\text { Car Accessories Shop Cashier } \\
\text { Supermarket Cashier } \\
\text { Cycle Repair Assistant } \\
\text { Supermarket Shelf Replenisher } \\
\text { Games Store Shop Assistant } \\
\text { Newsagents Sales Assistant }\end{array}$ \\
\hline $\begin{array}{l}\text { Catering } \\
\text { Pre-16 } \\
(\mathrm{n}=10)\end{array}$ & $\begin{array}{l}\text { Kerry } \\
\text { Jennifer } \\
\text { Tom } \\
\text { Helen } \\
\text { Gary } \\
\text { Grace } \\
\text { Shaun } \\
\text { Bryan } \\
\text { Lucy } \\
\text { Anna }\end{array}$ & $\begin{array}{l}\mathrm{F} \\
\mathrm{F} \\
\mathrm{M} \\
\mathrm{F} \\
\mathrm{M} \\
\mathrm{F} \\
\mathrm{M} \\
\mathrm{M} \\
\mathrm{F} \\
\mathrm{F}\end{array}$ & $\begin{array}{l}\text { Restaurant Waitress } \\
\text { Chip shop Server } \\
\text { Restaurant Kitchen Porter } \\
\text { Restaurant Front of House staff } \\
\text { Hotel Kitchen Porter } \\
\text { Golf club Waitress } \\
\text { Café/takeaway Assistant } \\
\text { Restaurant Kitchen Porter } \\
\text { Children's Play Centre Kitchen Assistant } \\
\text { Pizza takeaway Assistant }\end{array}$ \\
\hline $\begin{array}{l}\text { Catering } \\
16 \text {-plus }\end{array}$ & $\begin{array}{l}\text { Emma } \\
\text { Alison } \\
\text { Meg } \\
\text { Katy } \\
\text { David } \\
\text { Victoria } \\
\text { Linda } \\
\text { Elaine } \\
\text { Fraser }\end{array}$ & $\begin{array}{l}\mathrm{F} \\
\mathrm{F} \\
\mathrm{F} \\
\mathrm{F} \\
\mathrm{M} \\
\mathrm{F} \\
\mathrm{F} \\
\mathrm{F} \\
\mathrm{M}\end{array}$ & $\begin{array}{l}\text { Golf club Waitress } \\
\text { Café Waitress } \\
\text { Café Waitress } \\
\text { Children's Play Centre Kitchen Assistant } \\
\text { Pizza takeaway Trainee Manager } \\
\text { Café Waitress } \\
\text { Café Server } \\
\text { Fast food Operative } \\
\text { Fast food Operative }\end{array}$ \\
\hline
\end{tabular}

*Note: all participants chose their own pseudonym 
Table 2. Number of skills reported.

\begin{tabular}{c|c|c}
\hline & Mean & SD \\
\hline Retail & & 2.43 \\
\hline Pre-16 $(\mathrm{n}=6)$ & 9.5 & 2.85 \\
\hline 16-plus $(\mathrm{n}=10)$ & 8.9 & \\
\hline Catering & & 3.87 \\
\hline Pre-16 $(\mathrm{n}=10)$ & 8.5 & 2.87 \\
\hline $16-$ plus $(\mathrm{n}=9)$ & 9.7 & $\mathbf{2 . 6 3}$ \\
\hline Total Retail & & $\mathbf{3 . 3 9}$ \\
\hline Total Catering & $\mathbf{9 . 1}$ & \\
\hline Total Pre-16 & $\mathbf{9 . 1}$ & $\mathbf{3 . 3 4}$ \\
\hline Total 16-plus & & $\mathbf{2 . 8 1}$
\end{tabular}

$(n=35)$ 
Table 3. Future development of skills possible.

\begin{tabular}{|c|c|c|}
\hline & $\begin{array}{c}\text { Yes } \\
\mathrm{N}(\%)\end{array}$ & $\begin{array}{c}\text { No } \\
\mathrm{N}(\%) \\
\end{array}$ \\
\hline \multicolumn{3}{|l|}{ Retail } \\
\hline Pre-16 $(n=6)$ & $5(83)$ & $1(17)$ \\
\hline 16-plus $(n=9)$ & $6(67)$ & $3(33)$ \\
\hline \multicolumn{3}{|l|}{ Catering } \\
\hline Pre-16 $(n=9)$ & $1(11)$ & $8(89)$ \\
\hline 16-plus $(n=8)$ & $2(25)$ & $6(75)$ \\
\hline Total Retail & $11(73)$ & $4(27)$ \\
\hline Total Catering & $3(18)$ & $14(82)$ \\
\hline Total Pre-16 & $6(40)$ & $9(60)$ \\
\hline Total 16-plus & $8(47)$ & $9(53)$ \\
\hline
\end{tabular}

$(n=32)$ 
Figures; figure captions (as a list)

Figure 1. Type of skills identified, by group.

Word count 7556 